Emissions of Transport Refrigeration Units with CARB Diesel, Gas-to-Liquid Diesel, and Emissions Control Devices

R.A. Barnitt

National Renewable Energy Laboratory

D. Chernich and M. Burnitzki

California Air Resources Board

A. Oshinuga and M. Miyasato

South Coast Air Quality Management District

E. Lucht

Thermo King Corporation

D. van der Merwe

SasolChevron Consulting Limited

P. Schaberg

Sasol Technology

Presented at the 2009 SAE Powertrain, Fuels, and Lubricants Meeting San Antonio, Texas

November 2-4, 2009
Conference Paper NREL/CP-540-46598

May 2010 


\section{NOTICE}

The submitted manuscript has been offered by an employee of the Alliance for Sustainable Energy, LLC (ASE), a contractor of the US Government under Contract No. DE-AC36-08-GO28308. Accordingly, the US Government and ASE retain a nonexclusive royalty-free license to publish or reproduce the published form of this contribution, or allow others to do so, for US Government purposes.

This report was prepared as an account of work sponsored by an agency of the United States government. Neither the United States government nor any agency thereof, nor any of their employees, makes any warranty, express or implied, or assumes any legal liability or responsibility for the accuracy, completeness, or usefulness of any information, apparatus, product, or process disclosed, or represents that its use would not infringe privately owned rights. Reference herein to any specific commercial product, process, or service by trade name, trademark, manufacturer, or otherwise does not necessarily constitute or imply its endorsement, recommendation, or favoring by the United States government or any agency thereof. The views and opinions of authors expressed herein do not necessarily state or reflect those of the United States government or any agency thereof.

Available electronically at http://www.osti.gov/bridge

Available for a processing fee to U.S. Department of Energy and its contractors, in paper, from:

U.S. Department of Energy

Office of Scientific and Technical Information

P.O. Box 62

Oak Ridge, TN 37831-0062

phone: 865.576.8401

fax: 865.576 .5728

email: mailto:reports@adonis.osti.gov

Available for sale to the public, in paper, from:

U.S. Department of Commerce

National Technical Information Service

5285 Port Royal Road

Springfield, VA 22161

phone: 800.553 .6847

fax: 703.605 .6900

email: orders@ntis.fedworld.gov

online ordering: http://www.ntis.gov/ordering.htm 


\title{
Emissions of Transport Refrigeration Units with CARB Diesel, Gas-to-Liquid Diesel, and Emissions Control Devices
}

\author{
Robb A. Barnitt \\ National Renewable Energy Laboratory \\ Donald Chernich and Mark Burnitzki \\ California Air Resources Board \\ Adewale Oshinuga and Matt Miyasato \\ South Coast Air Quality Management District \\ Erich Lucht \\ Thermo King Corporation \\ Douw van der Merwe \\ SasolChevron Consulting Limited \\ Paul Schaberg \\ Sasol Technology
}

\begin{abstract}
A novel in situ method was performed for measuring emissions and fuel consumption of transport refrigeration units (TRUs). The test matrix included two fuels, two exhaust configurations, and two TRU engine operating speeds. The test fuels were California ultra low sulfur diesel and gas-to-liquid (GTL) diesel. The exhaust configurations were a stock original equipment manufacturer (OEM) muffler and a Thermo King pDPF diesel particulate filter. The two TRU engine operating speeds were high and low, as controlled by the TRU user interface.

Test results indicate that GTL diesel fuel reduces all regulated emissions at high and low engine operating speeds. Separately, the application of a Thermo King pDPF reduced regulated emissions, in some cases almost entirely. Finally, the application of both GTL diesel and a Thermo King pDPF reduced regulated emissions at high engine operating speed, but with an increase in oxides of nitrogen $\left(\mathrm{NO}_{\mathrm{x}}\right)$ at low engine speed.
\end{abstract}

\section{INTRODUCTION}

Transport refrigeration units (TRUs) are refrigeration systems designed to refrigerate or heat perishable products that are transported in various containers, including semi-trailers (Figure 1), box trucks, vans, shipping containers, and rail cars.

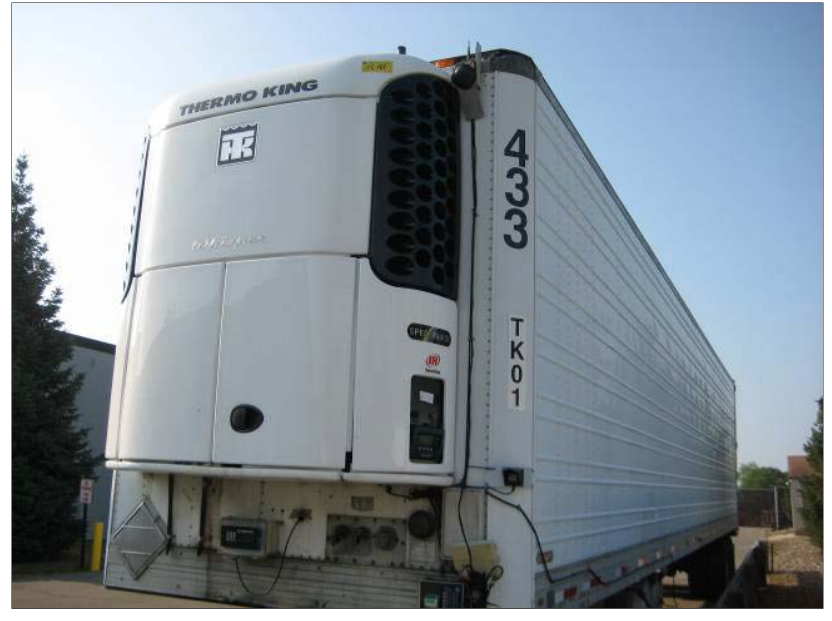

Figure 1. TRU Mounted on Trailer Nose 
TRUs are powered predominantly by diesel internal combustion engines. While TRU engines are relatively small, ranging from 9 to 36 horsepower (hp), significant numbers of vehicles with these engines congregate at distribution centers, truck stops, and other facilities, posing significant health risks to those who live and work nearby.

The California Air Resources Board (CARB) estimates that there are 40,200 TRUs operating in California at any given time, with an annual diesel consumption of more than 20 million gallons. CARB also estimates that TRU particulate matter (PM) and nitrogen oxides $\left(\mathrm{NO}_{\mathrm{x}}\right)$ emissions are 2 and 20 tons per day (tpd), respectively. The PM emission contribution from TRUs is estimated at $2.6 \%$ of total diesel PM emissions. PM emissions are projected to increase to about 2.5 tpd in 2010 and to more than 3 tpd by 2020 .

The nature of the TRU emissions inventory, as well as CARB's identification of diesel PM as a toxic air contaminant, led to CARB's adoption of an Airborne Toxic Control Measure (ATCM) for TRUs and TRU generator sets on February 26, 2004 . $^{1}$

The ATCM includes a phased compliance schedule based upon TRU model year; older units require compliance sooner. ${ }^{2}$ The three principal methods of compliance include the following:

1. Replacing the existing TRU engine with a certified engine meeting applicable nonroad/offroad emissions standards

2. Equipping the engine with a required level of Verified Diesel Emission Control Strategy (VDECS)

3. Operating a TRU or TRU gen set meeting one of several alternative technology options.

Alternative technology options include fuel cells, electric standby, cryogenic temperature control systems, alternative fuels with a VDECS, and alternative diesel fuels that have been verified as a VDECS. Examples of alternative diesel fuels include biodiesel and gas-toliquid (GTL) synthetic diesel. In on-road engines, GTL diesel fuel has been shown to reduce PM emissions without accompanying increases in other regulated emissions. ${ }^{3,4}$

There have been few studies on TRU emissions and performance with a VDECS or alternative technologies. $5,6,7$ Nevertheless, many parties are interested in the operability of and emissions from TRUs using various combinations of VDECS and alternative technologies:

- TRU end users (fleets) in need of operability data

- Regulators in need of emissions data

- TRU original equipment manufacturers (OEMs) in need of emissions data for compliance and operability data for warranties.

\section{OBJECTIVES}

This paper reports on one component of a larger collaborative project. The primary objective of the activities reported here was to measure the fuel consumption and emissions of a TRU fueled with GTL diesel or CARB ultra low sulfur diesel and equipped with either a Level 2 VDECS or the stock OEM muffler. Secondary objectives were to evaluate fuel consumption impacts due to backpressure with the Thermo King diesel particulate filter, known as pDPF, and to evaluate pDPF performance on equipment outside the terms of its CARB verification.

\section{APPROACH}

INTRODUCTION - This project was conducted under a cooperative research and development agreement between the U.S. Department of Energy's (DOE) National Renewable Energy Laboratory (NREL) and the South Coast Air Quality Management District (SCAQMD). Funding was supplied by SCAQMD and the Advanced Petroleum-Based Fuels Task sponsored by DOE's Vehicle Technologies Program. Additional project partners and their roles are listed in Table 1.

Table 1. Project Partners and Roles

\begin{tabular}{|l|l|}
\hline Project Partner & \multicolumn{1}{|c|}{ Project Role } \\
\hline NREL & Co-funder, project lead \\
\hline SCAQMD & Co-funder \\
\hline CARB & Emissions testing \\
\hline Thermo King & VDECS, engine teardown \\
\hline SasolChevron & $\begin{array}{l}\text { GTL diesel test fuel for in-use } \\
\text { evaluation and emissions testing }\end{array}$ \\
\hline
\end{tabular}

SYSTEM DESCRIPTION - The subject TRU is a model year 2004 Thermo King brand SB-200 30 model, mounted to a 48-foot trailer. The engine is a Yanmar 2.2 liter, four-cylinder in-line diesel. The engine utilizes mechanically direct injection and is naturally aspirated.

The engine shaft power is applied through a direct drive coupling to a refrigeration compressor off the flywheel. On the front of the engine, a belt system drives the alternator and an engine compartment cooling fan. The TRU operates at two engine speeds (1450 and 2200 rpm) which are mechanically governed by the fuel injection pump. A general TRU schematic is shown in Figure 2. The enclosure skins, electrical controls, belts, and blower are not shown. 


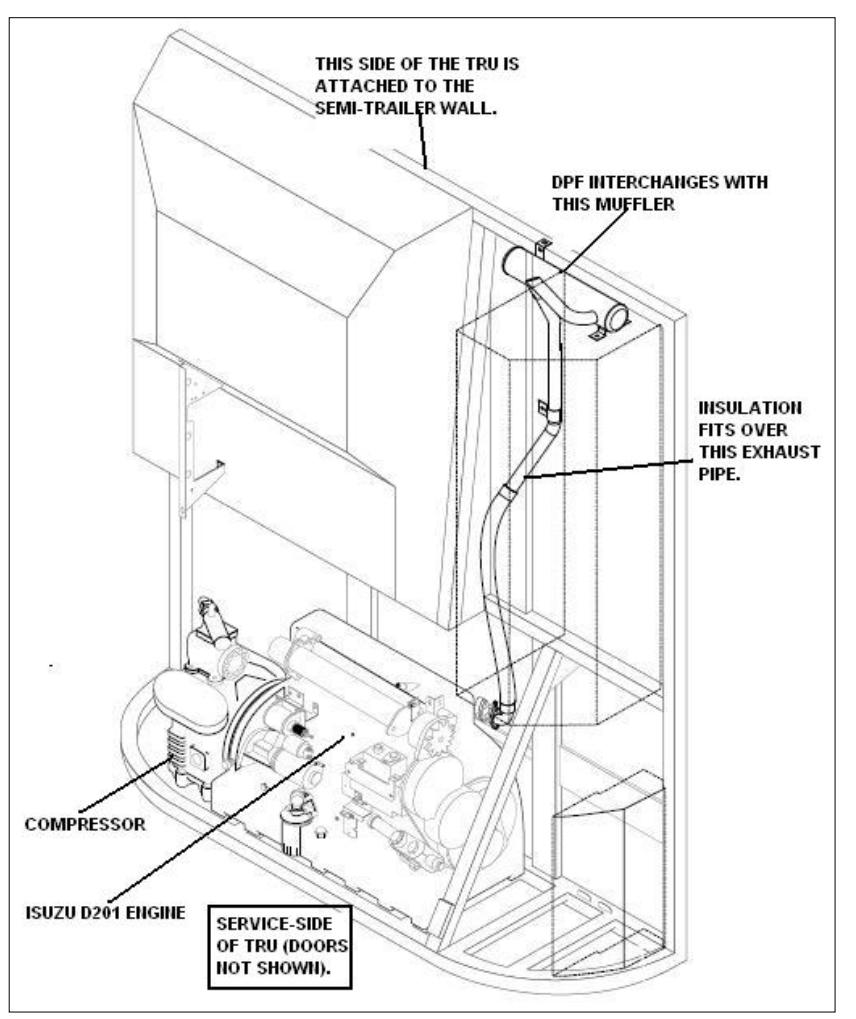

Figure 2. TRU Power Pack Schematic

EXHAUST AFTERTREATMENT - The Level 2 VDECS used in this testing is a Thermo King pDPF. The Thermo King pDPF was verified by CARB as a Level 2 device (achieves a greater than or equal to $50 \%$ reduction in diesel PM). Additionally, the Thermo King pDPF was found not to increase $\mathrm{NO}_{2}$ emissions more than $20 \%$ compared with the baseline, indicating compliance with the $2009 \mathrm{NO}_{2}$ emissions limit (13 CCR section 2706(a)) and thus obtaining designation as a "Plus" system per Section 2702(f). ${ }^{8}$ The CARB verification cited is for engine model years 2002 and older; the TRU unit tested is a model year 2004.

The principle of operation of the Thermo King pDPF is a flow-through design, utilizing knitted wire elements that provide a tortuous path. Passive regeneration of the soot is triggered by a proprietary catalyst on the mesh elements. The pDPF is designed to regenerate when the exhaust temperature is in the $230^{\circ} \mathrm{C}$ to $450^{\circ} \mathrm{C}$ range. A simple control system increases engine speed when a backpressure limit is reached to increase exhaust temperature and initiate soot regeneration. The wire mesh element is shown in Figure 3.

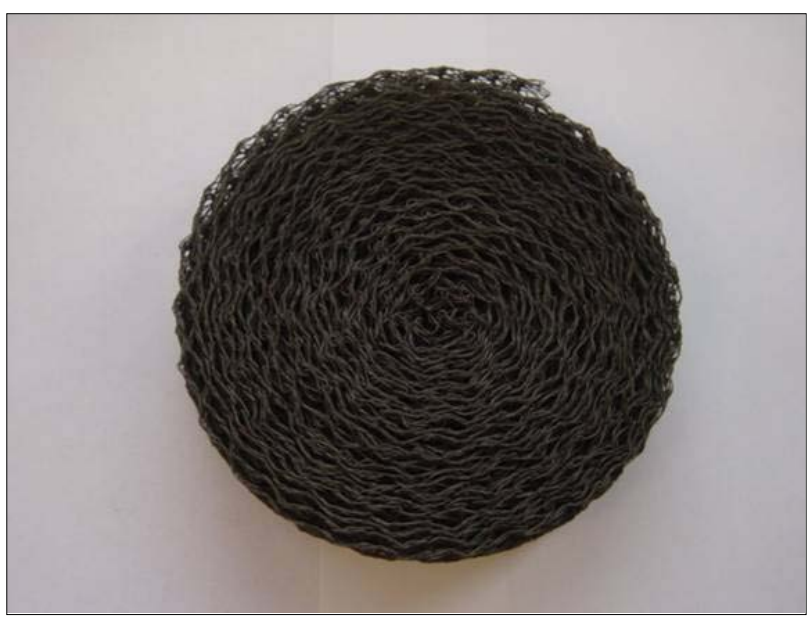

Figure 3. Thermo King pDPF Wire Mesh Element

TEST FUELS - Test fuels were CARB ultra low sulfur diesel and GTL diesel. CARB diesel was supplied by a local distributor of Chevron Products Company. This fuel was not analyzed but was presumed to meet the fuel specification for CARB diesel. CARB diesel is characterized by a maximum $10 \%$ by volume aromatics and minimum cetane number of 48 . SasolChevron supplied GTL diesel for emissions testing. This fuel was characterized by zero aromatic content and a cetane number of 81 . The appendix presents both the GTL diesel production lot analytical results and CARB diesel fuel specification for comparison.

EMISSIONS TESTING - TRU emissions and fuel consumption measurements were conducted at the CARB Stockton laboratory (SL). The CARB SL is a heavy-duty vehicle emissions laboratory configured to test heavy-duty diesel-powered vehicles on a twin roll, $1,100 \mathrm{hp}$ chassis dynamometer. In addition to wheeled vehicle tests, the SL can also perform emissions measurements on other utility equipment, such as TRUs and transportable air compressors.

All gaseous emissions were measured in the raw exhaust using conventional laboratory-grade analyzers manufactured by California Analytical Instruments. These included a heated flame ionization detector (HFID) for total hydrocarbon (THC) measurements, two heated chemiluminescence analyzers for total $\mathrm{NO}_{\mathrm{x}}$ and $\mathrm{NO}$ measurements, an infrared detector for $\mathrm{CO}$ and $\mathrm{CO}_{2}$ measurements, and a paramagnetic analyzer for $\mathrm{O}_{2}$ measurements. Air flow through the engine was measured using a calibrated air turbine installed on the engine air intake. 
PM was sampled by drawing a separate exhaust stream through a Sierra BG-2 partial flow sampling system (PFSS). The sampling stream temperature was held below $52^{\circ} \mathrm{C}$. PM samples were collected using a variety of dilution ratios and sampling times (depending on the test mode) on primary and secondary $90 \mathrm{~mm}$ T60A20 filter media. The filters were preconditioned in a temperature and humidity-controlled weighing room before and after sample collection and then measured gravimetrically on a Mettler Toledo UMX 2 microbalance.

Fuel consumption was measured using a gravimetric fuel measurement system integrated with a data acquisition system; both are manufactured by Superflow, Inc. A 22-gallon fuel can suspended by a torque cell provides real-time fuel consumption data. Both fuel supply and return lines are routed to the fuel can. Return fuel is passed through a water-to-fuel heat exchanger prior to being returned to the can. When in operation, the test equipment's fuel tank is bypassed completely, operating only on fuel supplied by the can.

Calibration is obtained through the use of certified weights placed on a purpose-designed stand. American Petroleum Institute (API) specific gravity is calculated by filling and emptying the can. The known volume, measured weight, and measured fuel temperature are used by the Superflow data acquisition system to calculate the API value, which is displayed as a data channel. Additional verification of the API value is obtained with the use of a temperature-corrected hydrometer.

The TRU was tested in situ as a complete operational unit. Unlike a certification test, the engine was not removed for testing on an engine dynamometer. The unaltered TRU was controlled using the Thermo King user interface, which controls the load placed on the diesel engine by varying the cooling command to the refrigerant compressor. Steady-state conditions were achieved by cooling the trailer box to a low temperature and then adjusting the cooling set point upward, resulting in a stabilized and repeatable engine load. This stabilized mode was verified by monitoring several parameters as a surrogate for direct load measurement. These stabilized load verification parameters included the refrigerant compressor high and low side pressures and fuel consumption. Continuous gaseous and engine operating conditions were recorded, and multiple PM filter samples were taken during the stabilized operation.

TEST MATRIX - Testing involved two fuels, two engine operating speeds, and two exhaust configurations. A total of eight combinations were tested with duplicate test runs (Table 2).
Table 2. TRU Test Matrix

\begin{tabular}{|c|l|l|l|}
\hline $\begin{array}{c}\text { Test } \\
\text { Run }\end{array}$ & \multicolumn{1}{|c|}{ Fuel } & $\begin{array}{c}\text { Engine } \\
\text { Speed }\end{array}$ & \multicolumn{1}{|c|}{ Exhaust } \\
\hline 1 & CARB diesel & Low & OEM muffler \\
\hline 2 & CARB diesel & High & OEM muffler \\
\hline 3 & CARB diesel & Low & pDPF \\
\hline 4 & CARB diesel & High & pDPF \\
\hline 5 & GTL Diesel & Low & OEM muffler \\
\hline 6 & GTL Diesel & High & OEM muffler \\
\hline 7 & GTL Diesel & Low & pDPF \\
\hline 8 & GTL Diesel & High & pDPF \\
\hline
\end{tabular}

The high and low TRU engine speeds are nominally 2200 and $1450 \mathrm{rpm}$, respectively. Between each fuel change, the fuel system was flushed clean and the engine was operated on the new test fuel for approximately two hours.

\section{RESULTS}

Steady-state conditions were achieved using the method described previously and confirmed by evaluating several key parameters. Engine speed (rpm), fuel consumption (gph), compressor outlet pressure (psi) and exhaust manifold temperature $\left({ }^{\circ} \mathrm{F}\right)$ were evaluated as indicators of steady-state operation. The figures below present one test that is representative of steady-state conditions achieved for all test runs. Engine speed and fuel consumption (Figure 4) and exhaust temperature and compressor outlet pressure (Figure 5) remain constant during the test procedure, indicating steadystate conditions.

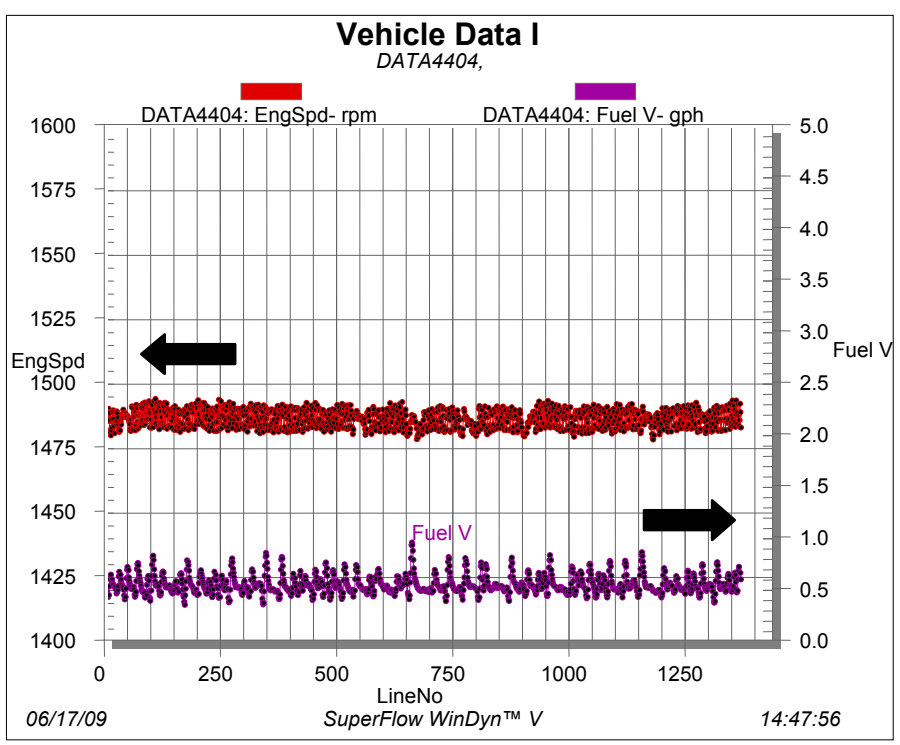

Figure 4. Steady-State Test Conditions for Engine Speed and Fuel Consumption 


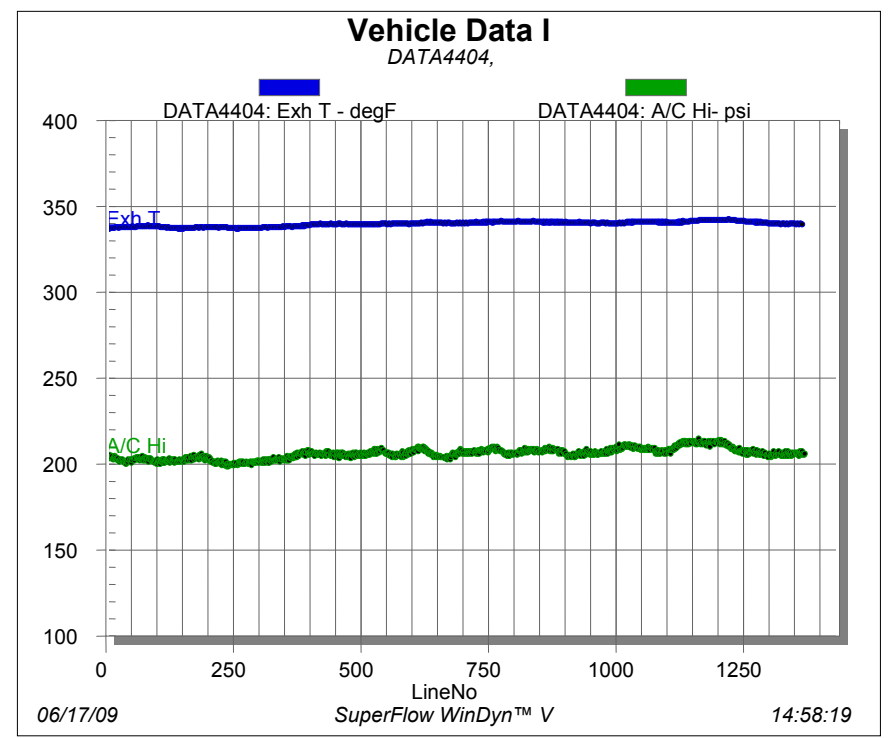

Figure 5. Steady-State Test Conditions for the Compressor High-Pressure Outlet and Exhaust Temperature

Gaseous emissions results also indicate that steadystate conditions were achieved using this test methodology (Figure 6). Downward spikes at consistent intervals are representative of emissions bench air injections and visually separate test runs.

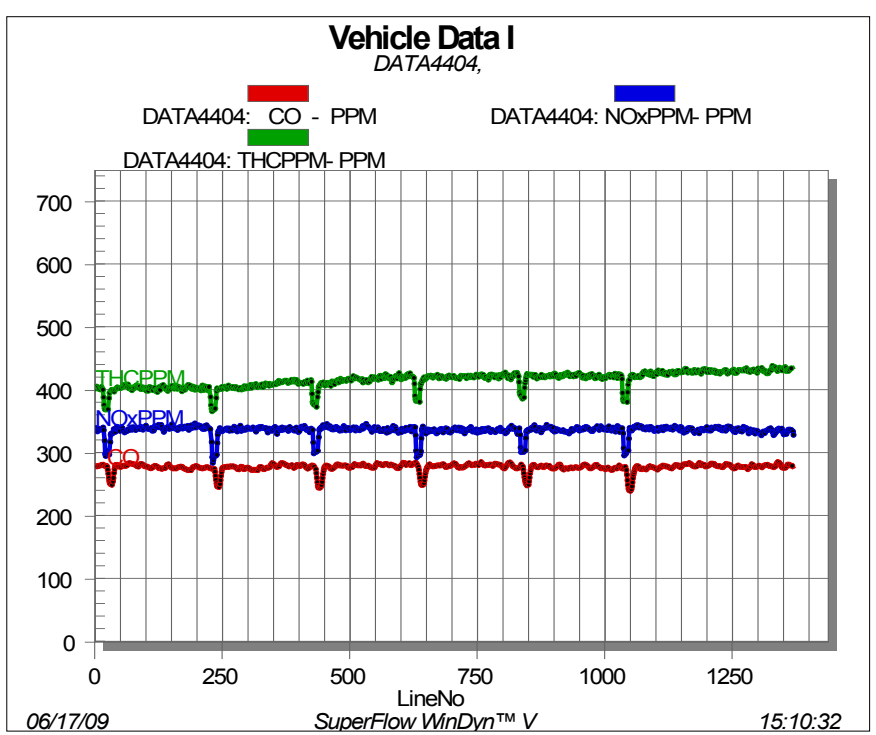

Figure 6. Steady-State Gaseous Emissions

Two runs per test configuration were conducted, and the results were averaged (Table 3 ). Two $\mathrm{NO}_{x}$ analyzers were used to measure total $\mathrm{NO}_{\mathrm{x}}$ and $\mathrm{NO}$. The $\mathrm{NO}_{2}$ and the ratio of $\mathrm{NO} / \mathrm{NO}_{2}$ were calculated and are also presented in Table 3 . The second $\mathrm{NO}_{x}$ analyzer failed during test runs of GTL diesel fuel with the pDPF; NO results are designated as not measured (NM).

Table 3. TRU Emissions Results

\begin{tabular}{|c|c|c|c|c|c|c|c|c|c|c|c|}
\hline Fuel & $\begin{array}{l}\text { Engine } \\
\text { Speed }\end{array}$ & Exhaust & $\begin{array}{l}\text { NOx } \\
\text { (g/hr) }\end{array}$ & $\begin{array}{c}\text { NO } \\
(\mathrm{g} / \mathrm{hr})\end{array}$ & $\begin{array}{c}\mathrm{NO}_{2} \\
(\mathrm{~g} / \mathrm{hr})\end{array}$ & $\begin{array}{l}\mathrm{NO} / \\
\mathrm{NO}_{2}\end{array}$ & $\begin{array}{c}\text { CO } \\
\text { (g/hr) }\end{array}$ & $\begin{array}{c}\mathrm{CO}_{2} \\
(\mathrm{~g} / \mathrm{hr})\end{array}$ & $\begin{array}{l}\text { THC } \\
\text { (g/hr) }\end{array}$ & $\underset{(\mathrm{g} / \mathrm{hr})}{\mathrm{PM}}$ & $\begin{array}{c}\text { Fuel } \\
\begin{array}{c}\text { Consumption } \\
\text { (gal/hr) }\end{array} \\
\end{array}$ \\
\hline CARB & High & Muffler & 123.34 & 104.37 & 18.96 & 5.50 & 61.80 & 17,975 & 37.28 & 17.60 & 1.31 \\
\hline GTL & High & Muffler & 107.49 & 90.11 & 17.38 & 5.18 & 49.94 & 17,834 & 29.21 & 12.89 & 1.35 \\
\hline CARB & High & pDPF & 123.95 & 92.08 & 31.87 & 2.89 & 0.73 & 19,715 & 1.56 & 13.98 & 1.33 \\
\hline GTL & High & pDPF & 108.97 & NM & NA & NA & 0.21 & 18,599 & 1.08 & 9.13 & 1.28 \\
\hline CARB & Low & Muffler & 53.89 & 41.67 & 12.21 & 3.41 & 30.77 & 6,222 & 24.92 & 6.49 & 0.56 \\
\hline GTL & Low & Muffler & 45.47 & 34.05 & 11.42 & 2.98 & 25.40 & 5,796 & 14.22 & 3.87 & 0.53 \\
\hline CARB & Low & pDPF & 52.38 & 45.58 & 6.80 & 6.70 & 10.40 & 6,423 & 17.50 & 2.77 & 0.51 \\
\hline GTL & Low & pDPF & 59.88 & NM & NA & NA & 0.69 & 5,532 & 5.94 & 1.81 & 0.48 \\
\hline
\end{tabular}

Emissions and fuel consumption duplicate test run results are compared across the test matrix in Figures $7-12$. 


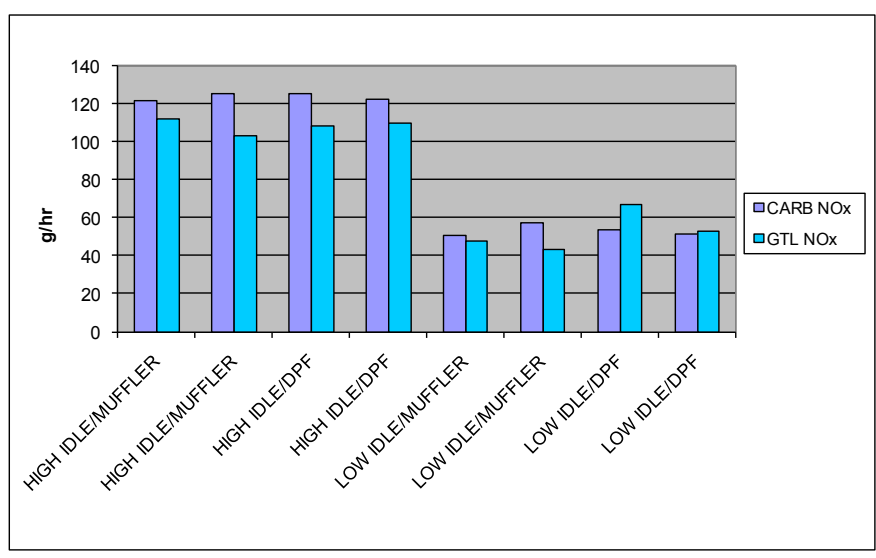

Figure 7. $\mathrm{NO}_{\mathrm{x}}$ Emissions

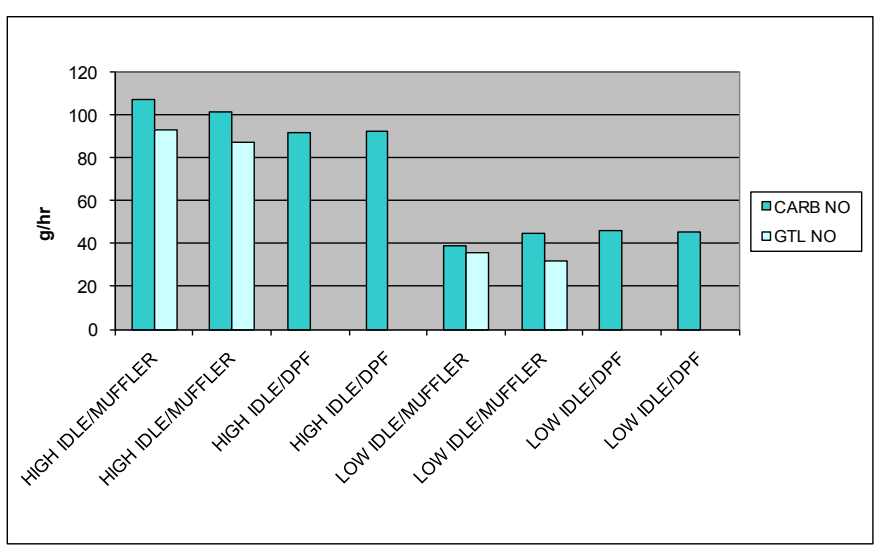

Figure 8. NO Emissions

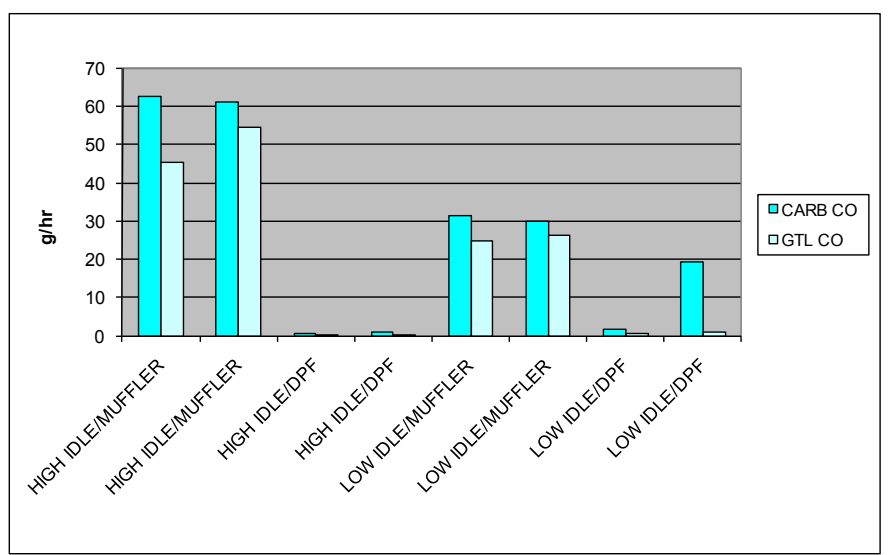

Figure 9. CO Emissions

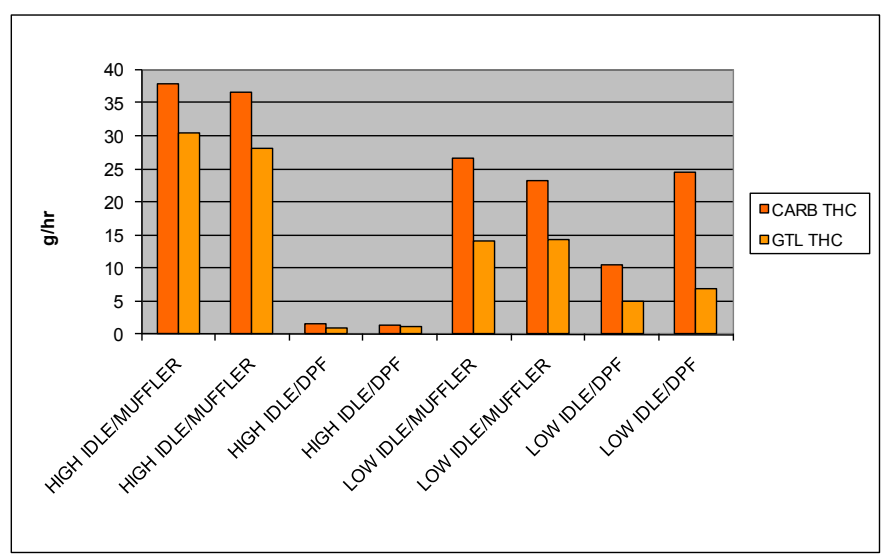

Figure 10. THC Emissions

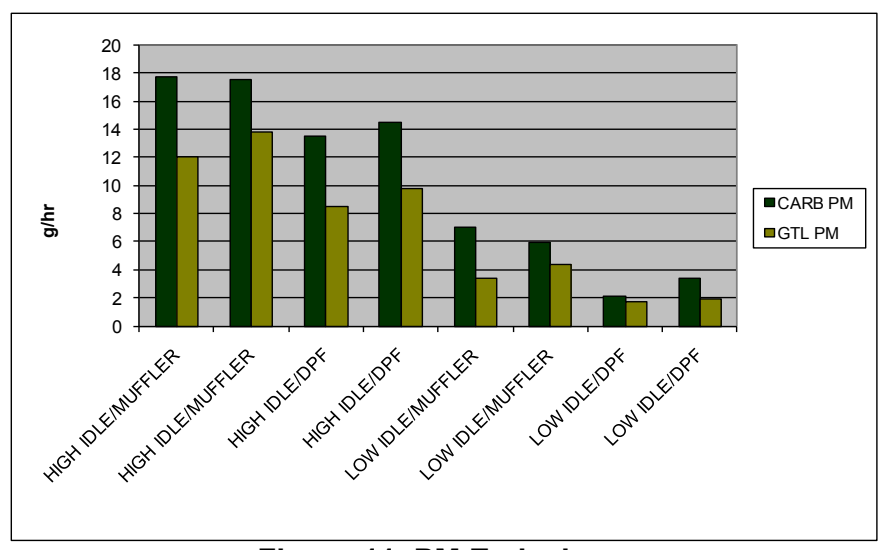

Figure 11. PM Emissions

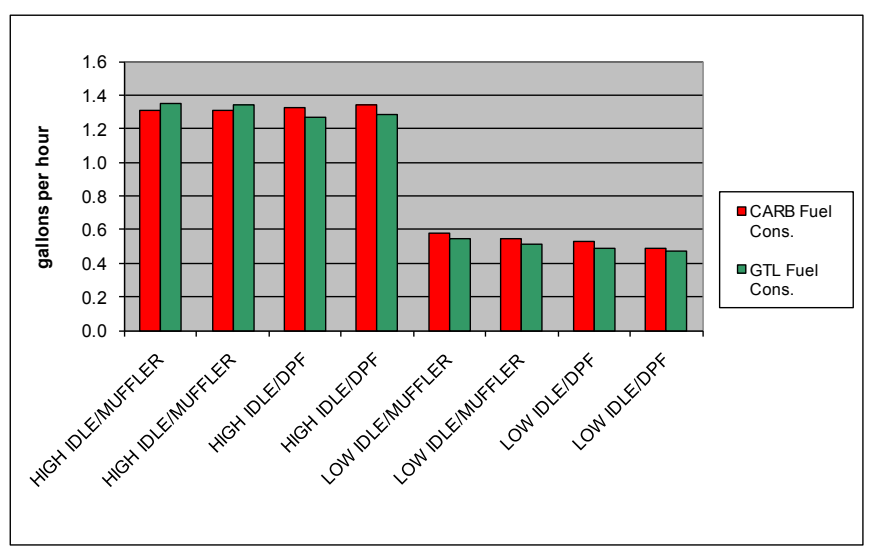

Figure 12. Fuel Consumption

Compared with the baseline condition of CARB diesel and a stock muffler, significant reductions of gaseous emissions and PM are possible when utilizing GTL diesel, a Thermo King pDPF, or combining the two approaches. Table 4 presents the percentage decreases measured in each case, and additional discussion follows. 
Table 4. Emissions Reductions with GTL Diesel and/or Thermo King pDPF

\begin{tabular}{|l|c|c|c|c|c|c|c|c|}
\hline $\begin{array}{l}\text { Engine } \\
\text { Speed }\end{array}$ & NO $_{\mathbf{x}}$ & NO & $\mathbf{N O}_{2}$ & $\mathbf{C O}$ & $\mathbf{C O}_{2}$ & THC & PM & $\begin{array}{c}\text { Fuel } \\
\text { Consumption }\end{array}$ \\
\hline Reductions with GTL diesel as replacement for CARB diese \\
\hline High & $-12.8 \%$ & $-13.7 \%$ & $-8.3 \%$ & $-19.2 \%$ & $-0.8 \%$ & $-21.7 \%$ & $-26.8 \%$ & $+2.9 \%$ \\
\hline Low & $-15.6 \%$ & $-18.3 \%$ & $-6.5 \%$ & $-17.4 \%$ & $-6.8 \%$ & $-42.9 \%$ & $-40.4 \%$ & $-6.4 \%$ \\
\hline Reductions with pDPF as replacement for muffler \\
\hline High & $+0.5 \%$ & $-11.8 \%$ & $+68.1 \%$ & $-98.8 \%$ & $+9.7 \%$ & $-95.8 \%$ & $-20.6 \%$ & $+2.0 \%$ \\
\hline Low & $-2.8 \%$ & $+9.4 \%$ & $-44.3 \%$ & $-66.2 \%$ & $+3.2 \%$ & $-29.8 \%$ & $-57.3 \%$ & $-9.3 \%$ \\
\hline Reductions with both GTL diesel and pDPF & & & & \\
\hline High & $-11.6 \%$ & NM & NA & $-99.7 \%$ & $+3.5 \%$ & $-97.1 \%$ & $-48.1 \%$ & $-2.2 \%$ \\
\hline Low & $+11.1 \%$ & NM & NA & $-97.8 \%$ & $-11.1 \%$ & $-76.2 \%$ & $-72.1 \%$ & $-14.4 \%$ \\
\hline
\end{tabular}

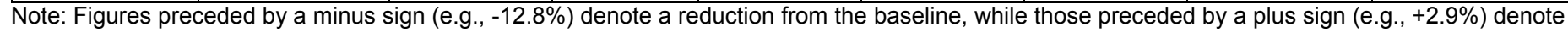
an increase.

Reductions in PM are the primary focus of the CARB ATCM and ultimately of this project. Replacing CARB diesel with GTL diesel yielded PM reductions of $27 \%-40 \%$, depending on engine speed. Replacing the OEM muffler with a Thermo King pDPF resulted in PM reductions of $21 \%-57 \%$, depending on engine speed. The application of both GTL diesel fuel and a Level 2 VDECS resulted in impressive, if not purely additive, reductions in PM of $48 \%-72 \%$. The Thermo King pDPF Level 2 VDECS CARB verification is specific to TRU engine model years 2002 and older. This Level 2 verification requires a $50 \%$ reduction in $\mathrm{PM}$ from baseline conditions (OEM muffler). While measured PM reductions in this case are less than $50 \%$ for the low engine speed test condition, note that (a) the engine vintage tested (2004) is outside the engine vintage verified (2002 or older), and (b) the verification data are based on an eight-mode engine test cycle, rather than the steady-state conditions measured in situ. Also noteworthy is that, while raw PM emissions are much lower at low engine speed, the relative percentage decreases are larger at low engine speed than they are at high engine speed.

Reductions in $\mathrm{NO}_{x}$ were expected with GTL diesel but not expected with the Thermo King pDPF. Replacing CARB diesel with GTL diesel yielded $\mathrm{NO}_{x}$ reductions of $13 \%-16 \%$, depending on engine speed. The ratio of $\mathrm{NO} / \mathrm{NO}_{2}$ was approximately the same across the two fuels. Replacing the OEM muffler with a Thermo King pDPF resulted in a slight increase in $\mathrm{NO}_{x}$ at high speed engine operation and a marginal decrease at low speed. The ratio of $\mathrm{NO} / \mathrm{NO}_{2}$ decreased at high engine speed (larger $\mathrm{NO}_{2}$ fraction), but increased at low engine speed (smaller $\mathrm{NO}_{2}$ fraction). The reason for this is unknown, although it can be presumed that low speed engine operation does not sufficiently light off the pDPF catalyst, resulting in a smaller oxidized $\mathrm{NO}_{\mathrm{x}}\left(\mathrm{NO}_{2}\right)$ fraction. The application of both GTL diesel fuel and a Level 2 VDECS resulted in a $\mathrm{NO}_{x}$ decrease of $12 \%$ at high engine speed, but an increase of $11 \%$ at low engine speed.
Reductions of $\mathrm{CO}$ and THC were expected with GTL diesel and generally expected with the pDPF because of its catalyzed nature. Replacing CARB diesel with GTL diesel yielded $\mathrm{CO}$ and THC reductions of $17 \%-19 \%$ and $22 \%-43 \%$, respectively, depending on engine speed. Replacing the OEM muffler with a Thermo King pDPF resulted in $\mathrm{CO}$ and $\mathrm{THC}$ reductions of $66 \%-99 \%$ and $30 \%-96 \%$, respectively, depending on engine speed. The application of both GTL diesel fuel and Level 2 VDECS resulted in dramatic $\mathrm{CO}$ and THC reductions of $98 \%-99 \%$ and $76 \%-97 \%$, respectively, depending on engine speed.

Differences in measured fuel consumption were observed across the test configurations. These differences were generally unexpected in terms of both magnitude and direction. However, raw fuel consumption values (Table 3 ) are generally small, in the hundredths of a gallon per hour. These differences are likely within the measurement error of the experimental equipment. It is unlikely that these differences were a function of the TRU or GTL diesel fuel. The TRU tested utilizes an engine with mechanically direct fuel injection. Thus, there were no subtle changes in fuel injection volume and timing due to the application of GTL diesel, with its significantly higher cetane number and lower density.

\section{CONCLUSIONS}

These in situ tests characterize the emissions from integrated TRUs rather than just the diesel engine. This methodology may yield relevant real-world TRU emissions profiles, providing better insight into the contribution of TRUs to emissions inventories. Integration of emissions over a period of time, including relative weighting of high and low idle times, is a logical extension to this work.

The use of GTL diesel fuel as a replacement to CARB diesel fuel can reduce gaseous emissions and PM at both high and low engine speeds. Replacement of the 
stock muffler with a Thermo King pDPF can also reduce some gaseous emissions and PM at both high and low TRU engine speeds. Compounded reductions, significant in the case of $\mathrm{CO}$ and THC, were realized in combining GTL diesel fuel with the Thermo King pDPF.

While there is no concrete explanation for the relative directional inversion of measured $\mathrm{NO}_{\mathrm{x}}$ and calculated $\mathrm{NO}_{2}$ and $\mathrm{NO} / \mathrm{NO}_{2}$ ratio with a pDPF test condition, it is likely that low engine speed operation does not sufficiently raise the catalyst temperature to enable light off and high efficiency oxidation. However, further investigation is warranted.

\section{ACKNOWLEDGMENTS}

The primary author wishes to thank the U.S. Department of Energy's Vehicle Technologies Program and Program Manager Kevin Stork. Also, the authors wish to acknowledge the contributions of Wayne Sobieralski, Roelof Riemersma, Robert lanni, Tullie Flower and Harlan Quan at CARB. Finally, the authors wish to acknowledge the generous assistance of Rockview Farms for the loan of the TRU and trailer for testing.

\section{REFERENCES}

1. http://www.arb.ca.gov/regact/trude03/trude03.htm.

2. http://www.arb.ca.gov/regact/trude03/fro1.pdf.

3. Alleman, T.L., et al. "Final Operability and Chassis Emissions Results from a Fleet of Class 6 Trucks Operating on Gas-to-Liquid Fuel and Catalyzed Diesel Particulate Filters," SAE 2005-01-3769.

4. Alleman, T.L., et al. "Fischer-Tropsch Diesel Fuels Properties and Exhaust Emissions: a Literature Review," SAE 2003-01-0763.

5. Mader, P., et al. "Emissions, Performance, and Duty Cycle Measurements of Diesel Powered TRUs," SAE 2007-01-1087.

6. Grupp, D., et al. "Design, Testing, and Demonstration of a Hybrid Fuel Cell Powered APU/TRU System," SAE 2007-01-0699.
7. Kulkarni, C.V., et al. "Modeling and Performance of Trailer Refrigeration Units with Alternative Power Systems," SAE 2007-01-764.

8. http://www.arb.ca.gov/diesel/verdev/level2/de-06008-02.pdf.

\section{CONTACT}

Robb Barnitt is a Senior Project Engineer at NREL. He can be reached at robb.barnitt@nrel.gov.

\section{ACRONYMS}

API: American Petroleum Institute

ATCM: Airborne Toxic Control Measure

CARB: California Air Resources Board

CO: carbon monoxide

$\mathrm{CO}_{2}$ : carbon dioxide

DOE: U.S. Department of Energy

g/hr: grams per hour

gal/hr: gallons per hour

gph: gallons per hour

GTL: gas-to-liquid

HFID: heated flame ionization detector

hp: horsepower

$\mathrm{mm}$ : millimeter

NA: not applicable

NM: not measured

NO: nitric oxide

$\mathrm{NO}_{\mathrm{x}}$ : oxides of nitrogen

$\mathrm{NO}_{2}$ : nitrogen dioxide

NREL: National Renewable Energy Laboratory

OEM: original equipment manufacturer

$\mathrm{O}_{2}$ : oxygen

PFSS: partial flow sampling system

PM: particulate matter

psi: pounds per square inch

rpm: revolutions per minute

SCAQMD: South Coast Air Quality Management District

SL: Stockton laboratory

tpd: tons per day

THC: total hydrocarbons

TRU: transport refrigeration unit

VDECS: verified diesel emission control strategy 


\section{APPENDIX}

\begin{tabular}{|c|c|c|c|c|}
\hline Component & Method & GTL Diese I & $\begin{array}{l}\text { CARB Diesel } \\
\text { (Specification) }\end{array}$ & Units \\
\hline Total Acid & ASTM D974 & $<0.001$ & & $\mathrm{mgKOH} / \mathrm{g}$ \\
\hline Appearance & ASTM D4176 & 1 & & \\
\hline Di Aromatic $\mathrm{H} / \mathrm{C}$ & \multirow{5}{*}{ IP 391/95 } & 0 & & mass \% \\
\hline Mono Aromatic $\mathrm{H} / \mathrm{C}$ & & 0 & & mass \% \\
\hline Poly Aromatic H/C & & 0 & $1.4 \max$ & mass \% \\
\hline Total Aromatic H/C & & 0 & $10 \max$ & mass \% \\
\hline Tri Aromatic $\mathrm{H} / \mathrm{C}$ & & 0 & & mass $\%$ \\
\hline Ash & ASTM D482 & $<0.01$ & & mass \% \\
\hline Carbon Residue & ASTM D4530 & 0.01 & & mass \% \\
\hline Cetane Number & ASTM D613 & 81.0 & $48 \mathrm{~min}$ & \\
\hline CFPP & ASTM D6371 & -6 & & $\operatorname{deg} C$ \\
\hline Cloud Point & ASTM D2500 & -4.4 & 2.2 & $\operatorname{deg} C$ \\
\hline Colour Lovibond & ASTM D1500 & 0 & & \\
\hline Total Contaminants & EN ISO 12662 & 3.1 & & $\mathrm{mg} / \mathrm{kg}$ \\
\hline Copper Corrosion & ASTM D130 & $1 \mathrm{~A}$ & & \\
\hline Density @ 20 & ASTM D4052 & 0.7708 & & $\mathrm{~kg} / \mathrm{l}$ \\
\hline $10 \%$ & \multirow{14}{*}{ ASTM D86 } & 208.6 & $205-255$ & $\operatorname{deg} C$ \\
\hline $20 \%$ & & 222.0 & & $\operatorname{deg} C$ \\
\hline $30 \%$ & & 235.5 & & $\operatorname{deg} C$ \\
\hline $40 \%$ & & 251.0 & & $\operatorname{deg} C$ \\
\hline $5 \%$ & & 199.1 & & $\operatorname{deg} C$ \\
\hline $50 \%$ & & 267.6 & $245-295$ & $\operatorname{deg} C$ \\
\hline $60 \%$ & & 284.5 & & $\operatorname{deg} C$ \\
\hline $70 \%$ & & 301.1 & & $\operatorname{deg} C$ \\
\hline $80 \%$ & & 319.3 & & $\operatorname{deg} C$ \\
\hline $90 \%$ & & 340.2 & $290-320$ & $\operatorname{deg} C$ \\
\hline $95 \%$ & & 354.2 & & $\operatorname{deg} C$ \\
\hline FBP & & 362.5 & & $\operatorname{deg} C$ \\
\hline IBP & & 175.7 & $170-215$ & $\operatorname{deg} C$ \\
\hline Recovery & & 99.0 & & vol \% \\
\hline Flash Point & ASTM D93 & 68 & $54 \mathrm{~min}$ & $\operatorname{deg} C$ \\
\hline Lubricity & ASTM D6079 & 349 & & WSD micrometre \\
\hline Oxidation Stability & ASTM D2274 & 0.4 & & $\mathrm{mg} / 100 \mathrm{ml}$ \\
\hline Total Sulphur & ASTM D5453 & 4 & $15 \max$ & $\mathrm{mg} / \mathrm{kg}$ \\
\hline Viscosity @ 40 Kin & ASTM D445 & 2.54 & $2.0-4.1$ & $\mathrm{cSt}$ \\
\hline
\end{tabular}




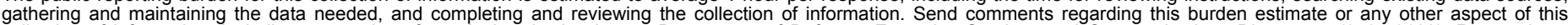

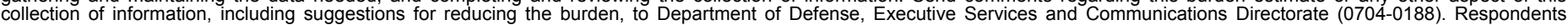

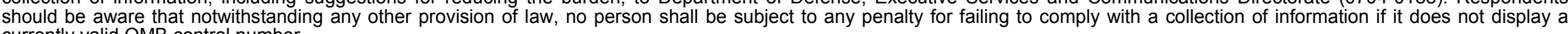

PLEASE DO NOT RETURN YOUR FORM TO THE ABOVE ORGANIZATION.
1. REPORT DATE (DD-MM-YYYY) May 2010
4. TITLE AND SUBTITLE
Emissions of Transport Refrigeration Units with CARB Diesel, Gas- to-Liquid Diesel, and Emissions Control Devices

3. DATES COVERED (From - To)

5a. CONTRACT NUMBER

DE-AC36-08-GO28308

5b. GRANT NUMBER

5c. PROGRAM ELEMENT NUMBER

5d. PROJECT NUMBER

NREL/CP-540-46598

5e. TASK NUMBER

FC08.8000

5f. WORK UNIT NUMBER Thermo King Corporation; D. van der Merwe, SasolChevron Consulting Limited; and P. Schaberg, Sasol Technology

7. PERFORMING ORGANIZATION NAME(S) AND ADDRESS(ES)

National Renewable Energy Laboratory

1617 Cole Blvd.

Golden, CO 80401-3393

9. SPONSORING/MONITORING AGENCY NAME(S) AND ADDRESS(ES)
8. PERFORMING ORGANIZATION REPORT NUMBER

NREL/CP-540-46598
10. SPONSOR/MONITOR'S ACRONYM(S) NREL

11. SPONSORING/MONITORING AGENCY REPORT NUMBER

12. DISTRIBUTION AVAILABILITY STATEMENT

National Technical Information Service

U.S. Department of Commerce

5285 Port Royal Road

Springfield, VA 22161

13. SUPPLEMENTARY NOTES

14. ABSTRACT (Maximum 200 Words)

A novel in situ method was used to measure emissions and fuel consumption of transport refrigeration units (TRUs). The test matrix included two fuels, two exhaust configurations, and two TRU engine operating speeds. Test fuels were California ultra low sulfur diesel and gas-to-liquid (GTL) diesel. Exhaust configurations were a stock muffler and a Thermo King pDPF diesel particulate filter. The TRU engine operating speeds were high and low, controlled by the TRU user interface. Results indicate that GTL diesel fuel reduces all regulated emissions at high and low engine speeds. Application of a Thermo King pDPF reduced regulated emissions, sometimes almost entirely. The application of both GTL diesel and a Thermo King pDPF reduced regulated emissions at high engine speed, but showed an increase in oxides of nitrogen at low engine speed.

15. SUBJECT TERMS

diesel engines ; diesel engine emissions ; gas-to-liquid diesel fuels ; transport refrigeration units ; TRUs; diesel particulate filters ; DPFs

\begin{tabular}{l} 
16. SECURITY CLASSIFICATION OF: \\
\begin{tabular}{|l|l|l|}
\hline $\begin{array}{l}\text { a. REPORT } \\
\text { Unclassified }\end{array}$ & b. ABSTRACT & c. THIS PAGE \\
& Unclassified & Unclassified \\
\hline
\end{tabular} \\
\hline
\end{tabular}

\begin{tabular}{l|l} 
17. LIMITATION \\
OF ABSTRACT \\
UL
\end{tabular}

19a. NAME OF RESPONSIBLE PERSON

19b. TELEPHONE NUMBER (Include area code) 